\title{
The changing use of the ovipositor in host shifts by ichneumonid ectoparasitoids of spiders (Hymenoptera, Ichneumonidae, Pimplinae)
} \author{
and Mark R. Shaw ${ }^{6, \dagger}$ \\ ${ }^{1}$ Institute for Advanced Biosciences, Keio University, Yamagata, Japan \\ ${ }^{2}$ Graduate School of Agricultural Science, Kobe University, Hyogo, Japan \\ ${ }^{3}$ Zoological Museum, University of Turku, Turku, Finland \\ ${ }^{4}$ Koto-ku, Tokyo, Japan \\ ${ }^{5}$ Osaka Museum of Natural History, Osaka, Japan \\ ${ }^{6}$ National Museums of Scotland, Edinburgh, UK
}

Keizo Takasuka ${ }^{1,2,{ }^{* \dagger}}$, Niclas R. Fritzén ${ }^{3, \dagger}$, Yoshihiro Tanaka ${ }^{4}$, Rikio Matsumoto ${ }^{5}$, Kaoru Maeto ${ }^{2}$,

Received 21 October 2017, Accepted 15 February 2018, Published online 28 March 2018

\begin{abstract}
Accurate egg placement into or onto a living host is an essential ability for many parasitoids, and changes in associated phenotypes, such as ovipositor morphology and behaviour, correlate with significant host shifts. Here, we report that in the ichneumonid group of koinobiont spider-ectoparasitoids ("polysphinctines"), several putatively ancestral taxa (clade I here), parasitic on ground-dwelling RTA-spiders (a group characterised by retrolateral tibial apophysis on male palpal tibiae), lay their eggs in a specific way. They tightly bend their metasoma above the spider's cephalothorax, touching the carapace with the dorsal side of the ovipositor apically ("dorsal-press"). The egg slips out from the middle part of the ventral side of the ovipositor and moves towards its apex with the parted lower valves acting as rails. Deposition occurs as the parasitoid draws the ovipositor backwards from under the egg. Oviposition upon the tough carapace of the cephalothorax, presumably less palatable than the abdomen, is conserved in these taxa, and presumed adaptive through avoiding physical damage to the developing parasitoid. This specific way of oviposition is reversed in the putatively derived clade of polysphinctines (clade II here) parasitic on Araneoidea spiders with aerial webs, which is already known. They bend their metasoma along the spider's abdomen, grasping the abdomen with their fore/mid legs, pressing the ventral tip of the metasoma and the lower valves of the ovipositor against the abdomen ("ventral-press"). The egg is expelled through an expansion of the lower valves, which is developed only in this clade and evident in most species, onto the softer and presumably more nutritious abdomen.
\end{abstract}

Keywords: Polysphinctine, Oviposition, Ventral-press, Dorsal-press, RTA-clade, Araneoidea

Résumé - Utilisation modifiée de l'ovipositeur au cours des changements d'hôte chez les ichneumonidés ectoparasitoïdes d'araignées (Hymenoptera, Ichneumonidae, Pimplinae). Le placement précis des œufs dans ou sur un hôte vivant est une capacité essentielle pour de nombreux parasitoïdes, et les changements dans les phénotypes associés, tels que morphologie des ovipositeurs et comportement, sont corrélés avec des changements significatifs d'hôte. Nous rapportons ici que dans le groupe des ichneumonidés koinobiontes ectoparasitoïdes d'araignées («polysphinctines»), plusieurs taxons putatifs ancestraux (clade I ici), parasites d'araignées terrestres RTA (un groupe caractérisé par une apophyse tibiale rétrolatérale sur les tibias des palpes mâles), pondent leurs oeufs d'une manière spécifique; ils courbent étroitement leur métasome au-dessus du céphalothorax de l'araignée, touchant apicalement la carapace avec le côté dorsal de l'ovipositeur («pression dorsale »). L'œuf s'écoule de la partie médiane du côté ventral de l'ovipositeur et se déplace vers son sommet avec les valves inférieures séparées agissant comme des rails, le dépôt de l'œuf se produisant lorsque le parasitoïde tire l'ovipositeur en arrière de sous l'œuf. La ponte sur la carapace dure du céphalothorax, vraisemblablement moins agréable au goût que l'abdomen, est conservée chez ces taxons, et présumée adaptative en évitant les dommages physiques au parasitoïde en développement. Cette voie spécifique de ponte est inversée dans le clade putatif dérivé des polysphinctines (clade II ici) parasites d'araignées Araneoidea avec des toiles aériennes, qui est déjà connu. Ils courbent leur métasome le long de l'abdomen de l'araignée, saisissent

\footnotetext{
*Corresponding author: keizaf@gmail.com

$\dagger$ These authors contributed equally to this work
} 
l'abdomen avec leurs pattes antérieures et médianes, pressent l'extrémité ventrale du métasome et les valves inférieures de l'ovipositeur contre l'abdomen («pression ventrale»). L'œuf est expulsé par une expansion des valves inférieures, qui est développée seulement dans ce clade et évidente dans la plupart des espèces, sur l'abdomen, plus doux et probablement plus nutritif.

\section{Introduction}

Oviposition is a crucial event in the life history of parasitoids [50] and placing the egg precisely into or onto a living host presents both behavioural and mechanical challenges. In addition to having a point sharp enough to pierce the integument of the host for the typical function of administering venom, the ovipositor in parasitoid wasps shows many structural adaptations for different functional behaviours $[12,42,104,106,109]$, derived from the ovipositor's base plan of an upper valve and a pair of more or less interlocking lower valves that can slide independently $[105,107]$. Apomorphic characters in its form can reflect phylogeny. In general, especially in the case of ichneumonoid ectoparasitoids of concealed hosts and endoparasitoids, the egg is expelled down a canal enclosed by the three valves to erupt near the ovipositor tip to reach an appropriate place for oviposition. However, in a few groups of ectoparasitoid ichneumonids with a koinobiont lifestyle (i.e. allowing the host to recover normal activity for a time after being attacked) in which the parasitoid can make direct bodily contact with the host, the egg may issue direct from the genital opening without involvement of the ovipositor, as is also seen in all aculeates which make similar contact with the food source of their offspring (briefly reviewed by Shaw \& Wahl [114]).

Ichneumonidae, in general, parasitise the pre-adult stages of holometabolous insects, with a few groups having adopted spider egg-sacs and egg-nests as pabula, their larvae devouring successive eggs. In some cases (Zaglyptus in the subfamily Pimplinae), the maternal egg-guardian of cursorial spiders (e.g. Eutichuridae making egg-nests) is permanently immobilised and also consumed [70,95]. Probably from this association with egg-nests by certain Pimplinae (in addition to Zaglyptus there is Tromatobia, which oviposits into exposed undefended egg-sacs or defended ones without paralysis of the guarding spider), the Polysphincta genus-group (hereafter polysphinctines) has evolved as a unique lineage of solitary koinobiont ectoparasitoids of spiders [48,86,131] (Fig. 1; see also Fig. 2 insets), widely demonstrated to be monophyletic $[48,86,108]$. Polysphinctines inject venom in the host's cephalothorax to cause temporarily paralysis for the purpose of oviposition, but after the egg is attached the spider recovers its normal activity until the parasitoid larva approaches full growth.

In a recent molecular study, Matsumoto [86] proposed two well-supported and reciprocally monophyletic major clades within this group: clade I, the Schizopyga subgroup sensu Matsumoto, and clade II equal to the Acrodactyla and Polysphincta subgroups sensu Matsumoto. Matsumoto [86] pointed out two ecological differences between the two clades: 1) they use different hosts and 2) the oviposition and hence larval development site on the host spider differs between the clades; larvae of clade I are exclusively attached to the cephalothorax while larvae of clade II are exclusively attached to the abdomen.

Matsumoto [86] regarded clade I as the more ancestral, with clade II being derived, and we outline our reasons for concurring with that view in the Discussion. However, the supposition that clade II is derived suggests of course that, if the polysphinctines are monophyletic as has been widely supported [48,86,108], the group called clade I will be paraphyletic with respect to clade II. In this paper, the relationship between the two supposed clades cannot be further elucidated, and "clade I" is used as a convenience term without the strict implication of unequivocal monophyly, though clade II is considered monophyletic.

For this paper, we have focused particularly on the behaviour of the group considered more ancestral (herein clade I), whose biology was previously poorly understood and for some groups unknown. Our detailed observations on the oviposition behaviour in both previously unstudied and already studied wasp genera strongly support the hypothesis proposed by Matsumoto [86] and we can show that the host groups used by the two wasp clades are not only ecologically but also phylogenetically different: clade I uses RTA-clade spiders (see Terminology) (hosts previously noted for three genera [36,37,85,86,95] and for a further two in this study), and clade II uses spiders of Araneoidea (numerous sources, see Table 1) with a single apparently secondary reversion (see Discussion). More importantly, we add a behavioural distinction regarding oviposition between the two clades, and additionally link differences in ovipositor morphology to the different behaviours.

\section{Terminology}

Cephalothorax: The fused head and thorax of spiders, also called the prosoma.

Carapace: A sclerotized plate covering the cephalothorax dorsally.

RTA-clade: A huge monophyletic lineage of spiders which was first proposed by Coddington and Levi, having retrolateral tibial apophysis (hence RTA) on male palpal tibiae [23]. Subsequently RTA has been consistently recognised to be a clear major (clade-defining) synapomorphy in many phylogenetic studies of Araneae $[1,13,22,44,59,60,90,122,143]$. The RTA-clade currently 


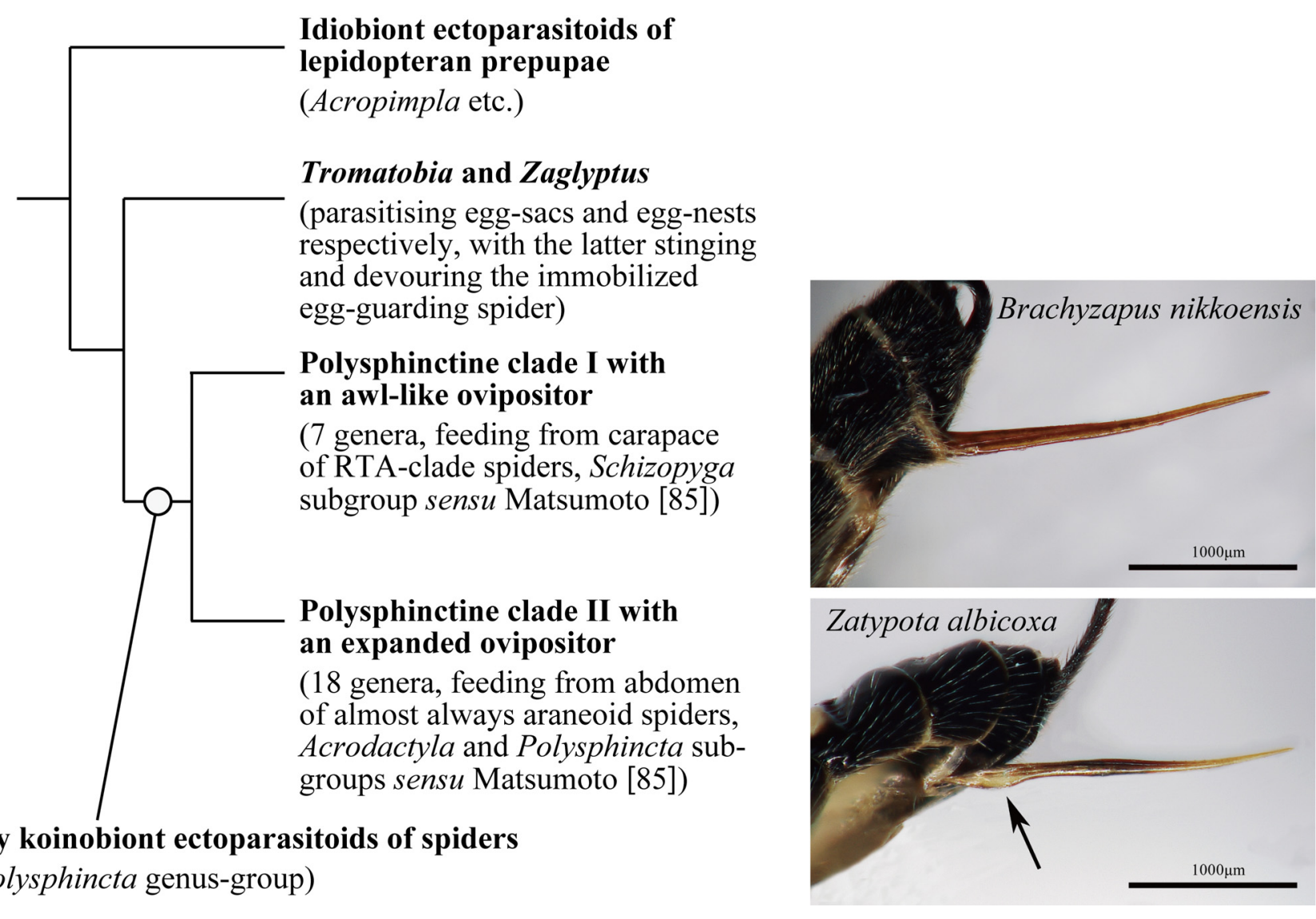

Solitary koinobiont ectoparasitoids of spiders

(The Polysphincta genus-group)

Figure 1. Simplified phylogenetic relationship within polysphinctine clades and its outgroups including spider egg-nest parasitoids, after Matsumoto [86]. The upper inserted photo is the awl-like ovipositor of Brachyzapus nikkoensis, a representative of clade I, and the lower one is the ovipositor of Zatypota albicoxa, a representative of clade II, with a ventral expansion at the proximal end of the lower valves (arrowed).

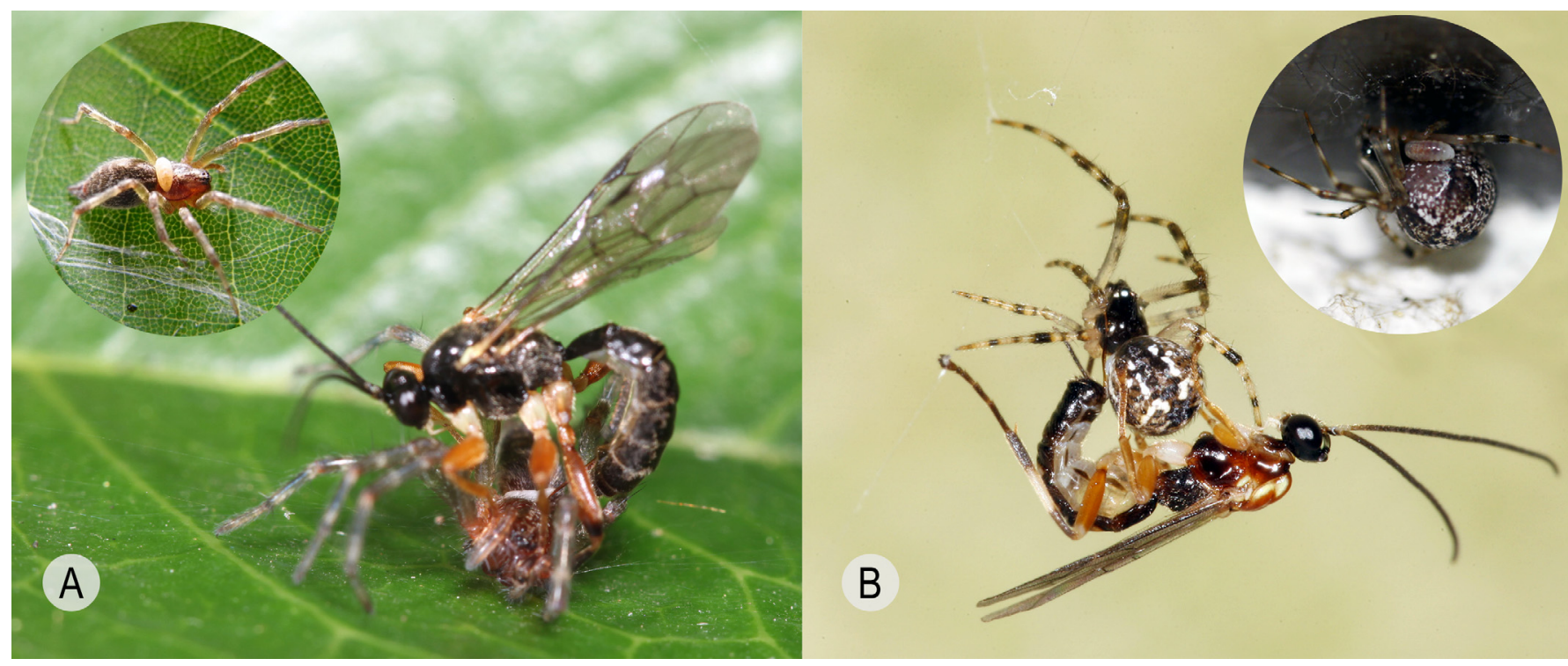

Figure 2. Oviposition by representative polysphinctines of clade I and II. A Brachyzapus nikkoensis (polysphinctine clade I) demonstrating the dorsal-press upon the cephalothorax of Agelena silvatica (Agelenidae), taken by Y.T. in Mizumoto Park, Tokyo, Japan in 14 June 2009. Circular inset is a middle instar larva of B. nikkoensis on the cephalothorax of A. silvatica. B Zatypota albicoxa (polysphinctine clade II) demonstrating the ventral-press upon the abdomen of Parasteatoda tepidariorum (Koch, 1841) [74] (Theridiidae), taken by Y.T. in Mizumoto Park, Tokyo, Japan in 6 August 2008. Circular inset is a middle instar larva of Z. albicoxa on the abdomen of $P$. tepidariorum. 
Table 1. Behaviour and ecology (immature position and host taxa) in polysphinctine clades I and II. Note that Hymenoepimecis robertsae parasitising a nephiline spider is mentioned here from a drawing suggesting the dorsal-press as in clade I [35]. Owing to the lack of behavioural description in the paper, we believe further observation is needed before the stance it truly manifests can be determined. Nothing is known about the immature biology of Dreisbachia, Inbioia (clade I), Aravenator, Chablisea, Lamnatibia, Pterinopus and Ticapimpla (clade II) at present. Taxa in which oviposition stance has not been specified are grouped under the generic name.

\begin{tabular}{|c|c|c|c|c|c|}
\hline Species & $\begin{array}{l}\text { Matsumoto's } \\
\text { clade }\end{array}$ & $\begin{array}{c}\text { Oviposition } \\
\text { stance }\end{array}$ & $\begin{array}{l}\text { Egg/larval } \\
\text { position }\end{array}$ & $\begin{array}{l}\text { Family of host } \\
\text { (web type) }\end{array}$ & Reference \\
\hline $\begin{array}{l}\text { Brachyzapus nikkoensis (Uchida, } \\
\text { 1928) [135] }\end{array}$ & clade I & $\begin{array}{l}\text { dorsal-press } \\
(\mathrm{n}=3)\end{array}$ & $\begin{array}{l}\text { cephalothorax } \\
{[69,85]}\end{array}$ & $\begin{array}{l}\text { Agelenidae } \\
\text { (plane funnel web) }\end{array}$ & $\begin{array}{l}\text { this study in } \\
\text { Japan }\end{array}$ \\
\hline Piogaster sp. & clade I & $\begin{array}{l}\text { dorsal-press } \\
(\mathrm{n}=6)\end{array}$ & $\begin{array}{l}\text { cephalothorax } \\
\text { [see also 113] }\end{array}$ & $\begin{array}{l}\text { Salticidae } \\
\text { (cursorial) }\end{array}$ & $\begin{array}{l}\text { this study in } \\
\text { Finland }\end{array}$ \\
\hline Zabrachypus sp. & clade I & $\begin{array}{l}\text { dorsal-press } \\
(\mathrm{n}=4)\end{array}$ & $\begin{array}{l}\text { cephalothorax } \\
\text { [see also 112] }\end{array}$ & $\begin{array}{l}\text { Titanoecidae } \\
\text { (ground-web) }\end{array}$ & $\begin{array}{l}\text { this study in } \\
\text { Europe }\end{array}$ \\
\hline $\begin{array}{l}\text { Iania pictifrons (Thomson, 1877) } \\
\text { [129] }\end{array}$ & clade I & $\begin{array}{l}\text { dorsal-press } \\
(\mathrm{n}=1)\end{array}$ & $\begin{array}{l}\text { cephalothorax } \\
{[36,37,113]}\end{array}$ & $\begin{array}{l}\text { Clubionidae } \\
\text { (cursorial) }\end{array}$ & $\begin{array}{l}\text { this study in } \\
\text { Finland }\end{array}$ \\
\hline $\begin{array}{l}\text { Schizopyga circulator (Panzer, } \\
1800)[101]\end{array}$ & clade I & dorsal-press & $\begin{array}{l}\text { cephalothorax } \\
\text { [also } 36,37]\end{array}$ & $\begin{array}{l}\text { Clubionidae } \\
\text { (cursorial) [also 36, } \\
37]\end{array}$ & {$[86]$} \\
\hline Schizopyga frigida Cresson,1870 [25] & clade I & unknown & cephalothorax & $\begin{array}{l}\text { Clubionidae } \\
\text { (cursorial) }\end{array}$ & {$[36,37]$} \\
\hline $\begin{array}{l}\text { Schizopyga podagrica Gravenhorst, } \\
1829 \text { [58] }\end{array}$ & clade I & unknown & cephalothorax & $\begin{array}{l}\text { Eutichuridae } \\
\text { (cursorial) }\end{array}$ & {$[95]$} \\
\hline $\begin{array}{l}\text { Reclinervellus tuberculatus (Uchida, } \\
\text { 1932) [136] }\end{array}$ & clade II & ventral-press & abdomen & Araneidae (orb web) & [87] \\
\hline $\begin{array}{l}\text { Hymenoepimecis argyraphaga } \\
\text { Gauld, } 2000 \text { [48] }\end{array}$ & clade II & ventral-press & abdomen & $\begin{array}{l}\text { Tetragnathidae (orb } \\
\text { web) }\end{array}$ & {$[30]$} \\
\hline $\begin{array}{l}\text { Hymenoepimecis veranii Loffredo } \\
\& \text { Penteado-Dias, } 2009 \text { [83] }\end{array}$ & clade II & ventral-press & abdomen & Araneidae (orb web) & {$[53]$} \\
\hline $\begin{array}{l}\text { Hymenoepimecis robertsae Gauld, } \\
1991 \text { [46] }\end{array}$ & clade II & $\begin{array}{l}\text { unclear } \\
\text { which stance } \\
\text { is used }\end{array}$ & abdomen & $\begin{array}{l}\text { Araneidae, } \\
\text { Nephilinae (orb web) }\end{array}$ & {$[35]$} \\
\hline Zatypota albicoxa & clade II & ventral-press & abdomen & Theridiidae (cobweb) & {$[127]$} \\
\hline $\begin{array}{l}\text { Zatypota maculata Matsumoto } \\
\text { \& Takasuka, } 2010[88]\end{array}$ & clade II & ventral-press & abdomen $[88]$ & Theridiidae (cobweb) & $\begin{array}{l}\text { K. Takasuka } \\
\text { (in prep.) in } \\
\text { Japan }\end{array}$ \\
\hline $\begin{array}{l}\text { Acrodactyla carinator (Aubert, } \\
\text { 1965) [3], A. degener (Haliday, } \\
\text { 1838) [62], A. quadrisculpta } \\
\text { (Gravenhorst, 1820) [57] }\end{array}$ & clade II & unknown & abdomen & $\begin{array}{l}\text { Tetragnathidae (orb } \\
\text { web); Linyphiidae } \\
\text { (3D web with a } \\
\text { sheet) }\end{array}$ & $\begin{array}{l}{[11,19,36,68} \\
77,86,89]\end{array}$ \\
\hline $\begin{array}{l}\text { Acrotaphus fuscipennis (Cresson, } \\
\text { 1865) [24], A. tibialis (Cameron, } \\
\text { 1886) [20], A. williti (Cresson, 1870) } \\
\text { [25] }\end{array}$ & clade II & unknown & abdomen & Araneidae (orb web) & {$[16,33,55]$} \\
\hline $\begin{array}{l}\text { Eriostethus minimus Gauld, } 1984 \\
\text { [45], E. rufus (Uchida, 1932) [136], } \\
\text { E. perkinsi (Baltazar, 1964) [6] }\end{array}$ & clade II & unknown & abdomen & $\begin{array}{l}\text { Araneidae (orb web), } \\
\text { Theridiidae (cobweb) }\end{array}$ & {$[76,86]$} \\
\hline $\begin{array}{l}\text { Eruga cf. gutfreundi Gauld, } 1991 \\
\text { [46], E. telljohanni Gauld, } 1991 \text { [46], } \\
\text { E. unilabiana Pádua \& Sobczak, } \\
2017 \text { [120] }\end{array}$ & clade II & unknown & abdomen & $\begin{array}{l}\text { Tetragnathidae (orb } \\
\text { web), Linyphiidae } \\
\text { (3D web with a } \\
\text { sheet) }\end{array}$ & {$[8,33,120]$} \\
\hline
\end{tabular}


Table1. (continued).

\begin{tabular}{|c|c|c|c|c|c|}
\hline Species & $\begin{array}{l}\text { Matsumoto's } \\
\text { clade }\end{array}$ & $\begin{array}{c}\text { Oviposition } \\
\text { stance }\end{array}$ & $\begin{array}{c}\text { Egg/larval } \\
\text { position }\end{array}$ & $\begin{array}{c}\text { Family of host } \\
\text { (web type) }\end{array}$ & Reference \\
\hline $\begin{array}{l}\text { Flacopimpla barathrica Fritzén, } \\
2014 \text { [40], F. parva (Cresson, 1870) } \\
\text { [25], F. varelae Gauld, } 1991 \text { [46] }\end{array}$ & clade II & unknown & abdomen & Theridiidae (cobweb) & {$[27,40,121]$} \\
\hline $\begin{array}{l}\text { Hymenoepimecis bicolor } \\
\text { (Brullé, 1846) [18], H. japi } \\
\text { Sobczak, Loffredo, Penteado- } \\
\text { Dias, \& Gonzaga, } 2009 \text { [117], } \\
\text { H. jordanensis Loffredo } \\
\text { \& Penteado-Dias, } 2009 \text { [83], } \\
\text { H. manauara Pádua \& Oliveira, } \\
\text { 2016 [98], H. neotropica } \\
\text { (Brues \& Richardson, 1913) [17], } \\
\text { H. silvanae Loffredo \& } \\
\text { Penteado-Dias, 2009 [83], } \\
\text { H. sooretama Sobczak, Loffredo, } \\
\text { Penteado-Dias, \& Gonzaga, } \\
\text { 2009 [117], H. tedfordi Gauld, } \\
\text { 1991 [46] }\end{array}$ & clade II & unknown & abdomen & $\begin{array}{l}\text { Araneidae (orb web); } \\
\text { Araneidae, } \\
\text { Nephilinae } \\
\text { (orb web); } \\
\text { Araneidae, } \\
\text { Cyrtophorinae } \\
\text { (3D web with a } \\
\text { dome-shape } \\
\text { platform); } \\
\text { Tetragnathidae } \\
\text { (orb web) }\end{array}$ & $\begin{array}{l}{[33,52,54,98,} \\
115-117]\end{array}$ \\
\hline Longitibia sp. & clade II & unknown & abdomen & $\begin{array}{l}\text { Linyphiidae ( } 3 \mathrm{D} \text { web } \\
\text { with a sheet) }\end{array}$ & $\begin{array}{l}\text { R. Matsumoto } \\
\text { and K. } \\
\text { Takasuka } \\
\text { (unpublished) } \\
\text { in Japan }\end{array}$ \\
\hline $\begin{array}{l}\text { Megaetaira madida (Haliday, 1838) } \\
\text { [62], M. varicarinata (Uchida \& } \\
\text { Momoi, 1958) [138] }\end{array}$ & clade II & unknown & abdomen & $\begin{array}{l}\text { Tetragnathidae (orb } \\
\text { web) }\end{array}$ & {$[36,63,92]$} \\
\hline $\begin{array}{l}\text { Oxyrrhexis carbonator } \\
\text { (Gravenhorst, } 1807) \text { [56], } \\
\text { O. carbonator texana } \\
\text { (Cresson, } 1870) \text { [25], } \\
\text { O. zephyrus } \text { Fritzén, } \\
2014 \text { [41] }\end{array}$ & clade II & unknown & abdomen & Theridiidae (cobweb) & {$[26,41]$} \\
\hline
\end{tabular}

\begin{tabular}{|c|c|c|c|c|c|}
\hline $\begin{array}{l}\text { Polysphincta boops Tschek, } 1869 \\
\text { [133], P. gutfreundi Gauld, } 1991 \\
{[46], \text { P. janzeni Gauld, } 1991[46],} \\
\text { P. koebelei Howard, } 1892[67], \\
\text { P. longa Kasparyan, } 1976 \text { [71], } \\
\text { P. sp. nr. purcelli Gauld, } 1991 \text { [46], } \\
\text { P. rufipes Gravenhorst, } 1829 \text { [58], } \\
\text { P. tuberosa Gravenhorst, } 1829 \text { [58] }\end{array}$ & clade II & unknown & abdomen & Araneidae (orb web) & $\begin{array}{l}{[7,14,32,36,43} \\
72,73,78,111]\end{array}$ \\
\hline $\begin{array}{l}\text { Reclinervellus masumotoi } \\
\text { Matsumoto \& Konishi, 2007 [87], } \\
\text { R. nielseni (Roman, 1923) [110] }\end{array}$ & clade II & unknown & abdomen & Araneidae (orb web) & $\begin{array}{l}{[38,69,87,} \\
124,128]\end{array}$ \\
\hline $\begin{array}{l}\text { Sinarachna nigricornis (Holmgren, } \\
\text { 1860) [65], S. pallipes (Holmgren, } \\
\text { 1860) [65] }\end{array}$ & clade II & unknown & abdomen & Araneidae (orb web) & {$[36,37,93]$} \\
\hline Zatypota spp. (numerous) & clade II & unknown & abdomen & $\begin{array}{l}\text { Theridiidae } \\
\text { (cobweb); } \\
\text { Linyphiidae (3D web } \\
\text { with a sheet); } \\
\text { Dictynidae } \\
\text { (cobweb); Araneidae } \\
\text { (orb web) }\end{array}$ & $\begin{array}{l}{[7,9,31,39,40,51,} \\
66,67,75,79,80, \\
88,119,124,140, \\
142]\end{array}$ \\
\hline
\end{tabular}


consists of 43 families in eight higher groups in accordance with Wheeler et al. [143], which are largely vagabonds or ground web weavers. The superfamily Titanoecoidea has been proposed to be an immediate outgroup of the RTAclade $[60,143]$.

\section{Materials and methods}

We observed oviposition behaviour of several European and Japanese polysphinctine species in vitro and in the field, parts of which will be published in detail later. Zatypota albicoxa (Walker, 1874) [141], a member of clade II, for which oviposition behaviour is already known [125127], was also looked at in more detail for corroboration and comparison with clade I. We focused especially on how the wasps use their ovipositor when ovipositing. The known behaviour of polysphinctines from published sources (mainly clade II), together with our new findings, are listed in Table 1 (Oviposition stance). In addition to behaviour, data on egg position (Egg/larval position) and host family records with their web type in parenthesis (Family of host) given in Table 1 has been gleaned from the literature when either description or illustration has been unequivocal.

For data on ovipositor morphology, we largely follow Gauld \& Dubois [48], but we have personally checked species of most of the polysphinctine genera, particularly focusing on species and literature concerning genera where our observations on ovipositor morphology differ from that indicated in Gauld \& Dubois [48] (Oxyrrhexis) or for genera of particular interest for their ovipositor morphology (e.g. Oxyrrhexis and Chablisea).

\section{Results}

\section{Oviposition stance}

We first discovered that Brachyzapus nikkoensis, belonging to clade I of the polysphinctines, lays its egg on the host spider ( 3 observations in total by 2 individuals in Tokyo, Japan in June 2009, host Agelena silvatica Oliger, 1983 [97], Agelenidae) in a rather specific way, contrasting with what we had seen in other genera (belonging to clade II). After temporarily paralysing the spider by stinging into its cephalothorax, the wasp initially bends its metasoma inward underneath its body with the dorsal tip of its metasoma and, in particular, the dorsal side of the ovipositor's apical part touching the spider's carapace (dorsal-press, Figs. 2A, 3A-d, S1). It then stretches the metasoma out (Fig. 3A-d, S1) while the egg is expelled onto the spider's carapace. When doing this, the wasp grasps the host's cephalothorax with its legs, having its head and ovipositor both pointing in the same direction, and the wasp thus has visibility of the oviposition site. Later, our studies on members of a further three genera, Piogaster sp. (cf. pilosator Aubert, 1958 [2]) in Finland in 2015 and 2016 ( 6 observations in total by 2 individuals, host Salticus cingulatus (Panzer, 1797) [100],
Salticidae), Zabrachypus sp. from Germany ex Titanoeca quadriguttata (Hahn, 1833) [61] in 2015 (4 observations in total by 3 individuals, surrogate Finnish host Titanoeca spominima (Taczanowski, 1866) [123], Titanoecidae) and Iania pictifrons in Finland in 2016 (1 observation, host Clubiona subsultans Thorell, 1875 [130], Clubionidae), showed that this behaviour was the common one for clade I. Additionally, Matsumoto [86] gives a photograph of Schizopyga circulator clearly ovipositing on Clubiona rostrata Paik, 1985 [99] (Clubionidae) in the same way. In ovipositions by $B$. nikkoensis studied in situ and Piogaster sp. studied in vitro, the subjugated host lay prone (the ventral side below) on the plane sheet web or the substrate with the parasitoid sitting astride. Concerning I. pictifrons and Zabrachypus sp. studied in vitro, at least occasionally the temporarily paralysed spider can be hanging from its silk with the parasitoid almost being upside down but still employing the typical dorsal-press action and ovipositing onto the carapace.

For the species in clade II, the movement of the metasoma during oviposition is very different. The female presses the ventral tip of its metasoma against the spider, making contact with the ventral side of at least the base of the ovipositor, and pulls the metasoma inward (ventralpress, Figs. 2B, 3B-d, S2), while the egg is expelled onto the spider's abdomen. When doing this, the wasp uses its legs more widely to grasp the abdomen and surrounds, and the head of the wasp is far away from the oviposition site (on small host specimens it may even be on the opposite side of the host) with the ovipositor tip and head pointing in opposite directions. Thus, it has little or no visibility of the oviposition site.

\section{Oviposition site}

In clade I, the egg is applied exclusively to the carapace of the host's cephalothorax (Figs. 2A, 3A-c) (with our two additions, Zabrachypus and Piogaster, it is recorded in altogether five of the seven genera of clade I, Table 1) whereas in clade II it is attached exclusively to the abdomen of the host (Figs. 2B, 3B-c), corroborated by many sources without exception (observed in 13 out of the 18 genera of clade II, Table 1).

\section{Egg expulsion}

At least in B. nikkoensis $(\mathrm{n}=3)$ and Piogaster sp. $(\mathrm{n}=1)$ (less complete observations on I. pictifrons $(\mathrm{n}=1)$, and Zabrachypus sp. $(\mathrm{n}=1)$ are consistent but inexact) the egg issues from the middle part of the ventral side of the ovipositor (Fig. 3A-b) and is guided distally along the ovipositor with the parted lower valves acting as rails (Fig. 3A-c), finally being placed onto the carapace as the ovipositor is withdrawn backwards from under it. In the species of clade II that we have studied, the egg is expelled neither from the middle region of the ovipositor nor from the genital opening but from near the base of the ovipositor (Figs. 2B, 3B-b). Egg expulsion ensues here at the site of 


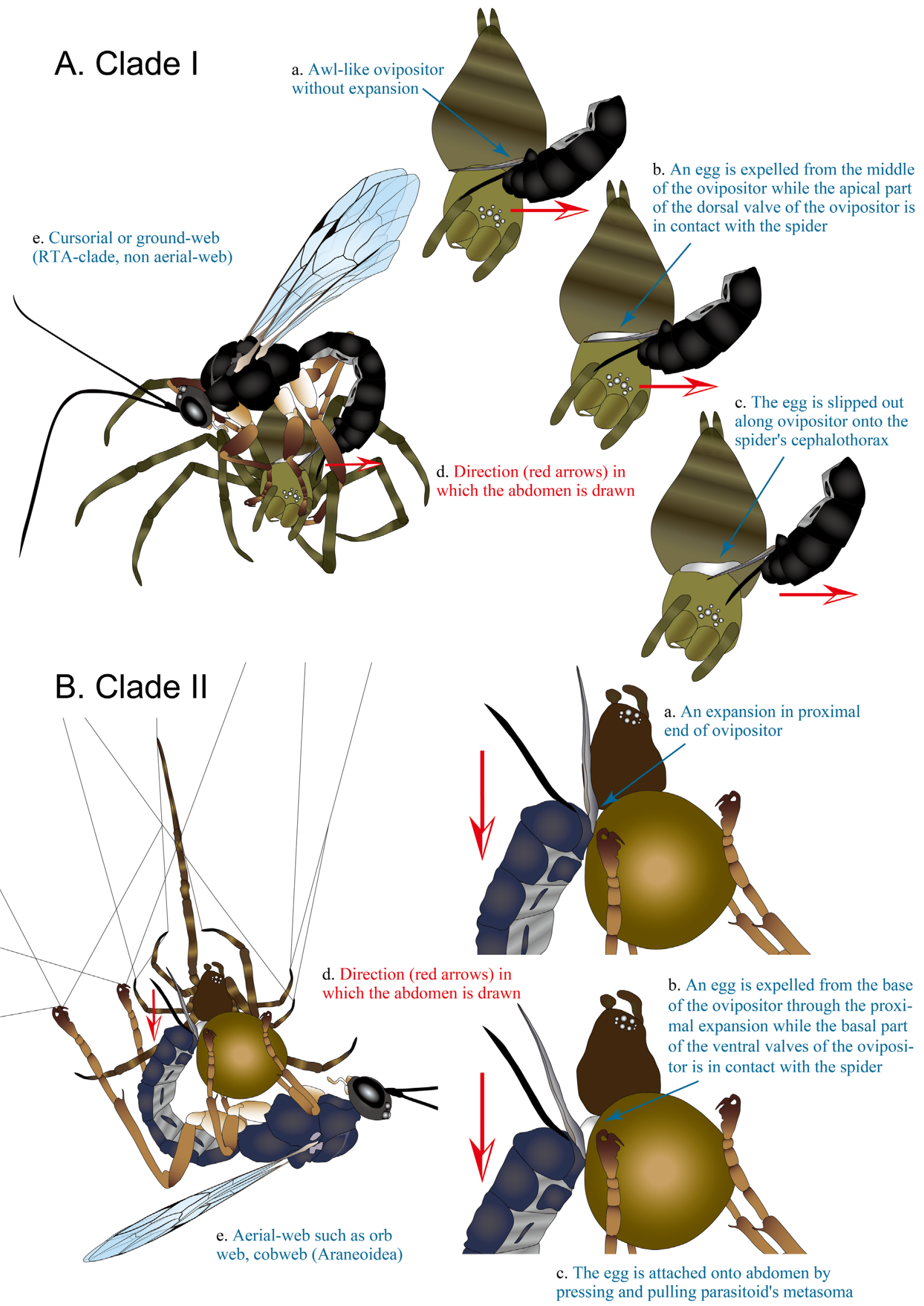

Figure 3. Schematic diagram of oviposition behaviour and egg-expulsion. A the dorsal-press of clade I, B the ventral-press of clade II. Lowercase symbols are explanations of characteristics that differ between the two clades. 

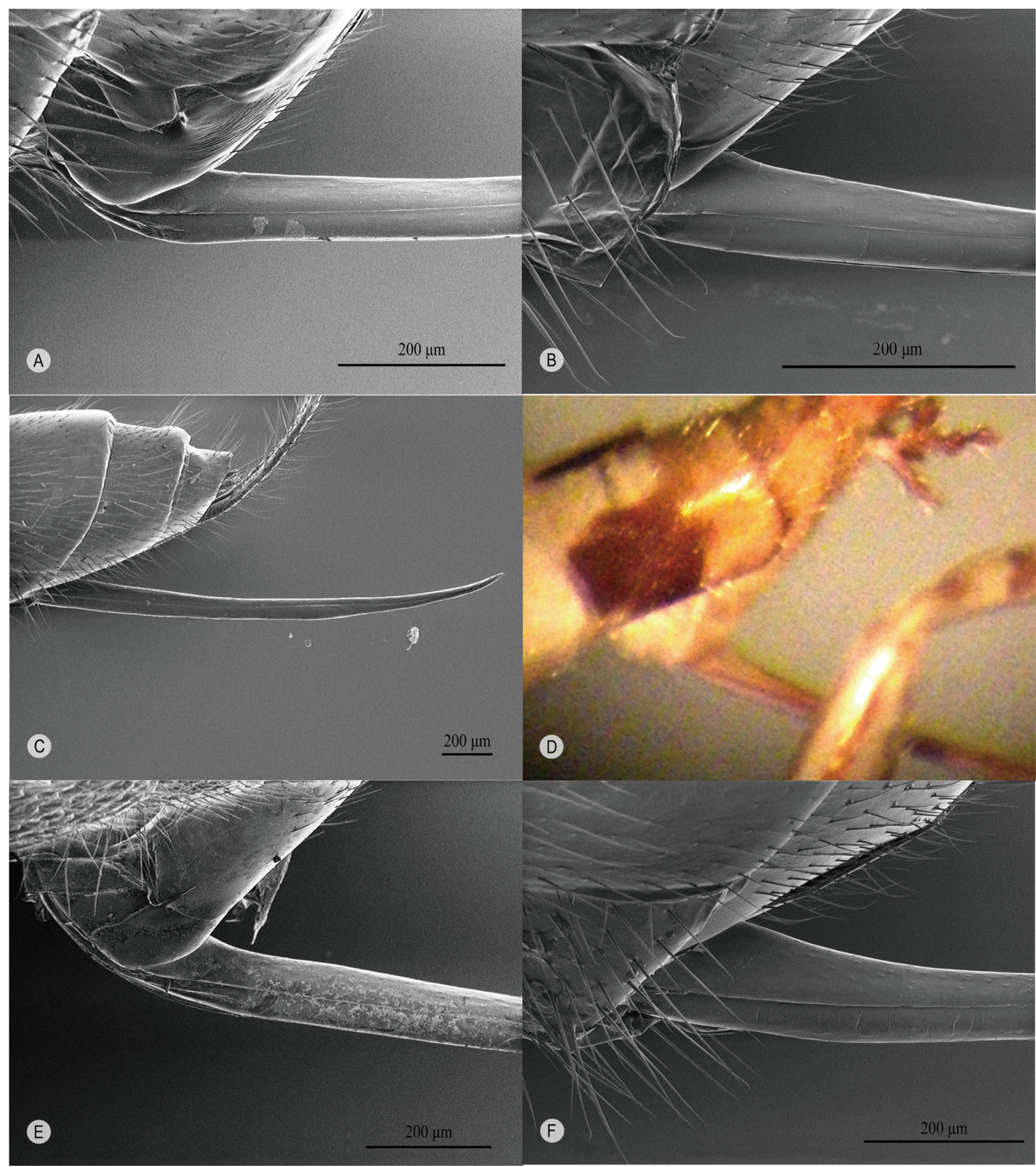

Figure 4. Awl-like ovipositor of clade I spp. with no ventral expansion at the proximal end. A Brachyzapus nikkoensis, B Dreisbachia punctata (Uchida \& Momoi, 1959) [139], C Iania sp., D Inbioia pivai Gauld \& Ugalde Gómez, 2002 [49] (holotype in NHM), E Piogaster daisetsuzana Kusigemati, 1985 [81], F Schizopyga frigida.

an expansion of the lower valves of the ovipositor (Figs. 1 arrow, 3B-a). During oviposition in both dorsal-press and ventral-press behaviours, the ovipositor itself is finally withdrawn in the same overall direction in relation to the egg, while the egg is placed (S1, S2).

\section{Ovipositor morphology of clades I and II}

The base of the ovipositor is ventrally simple (Figs. 1 upper inset, 3A-a, 4) in all known genera of clade I, whereas in most genera of clade II, it is distinctly expanded (Figs. 1 


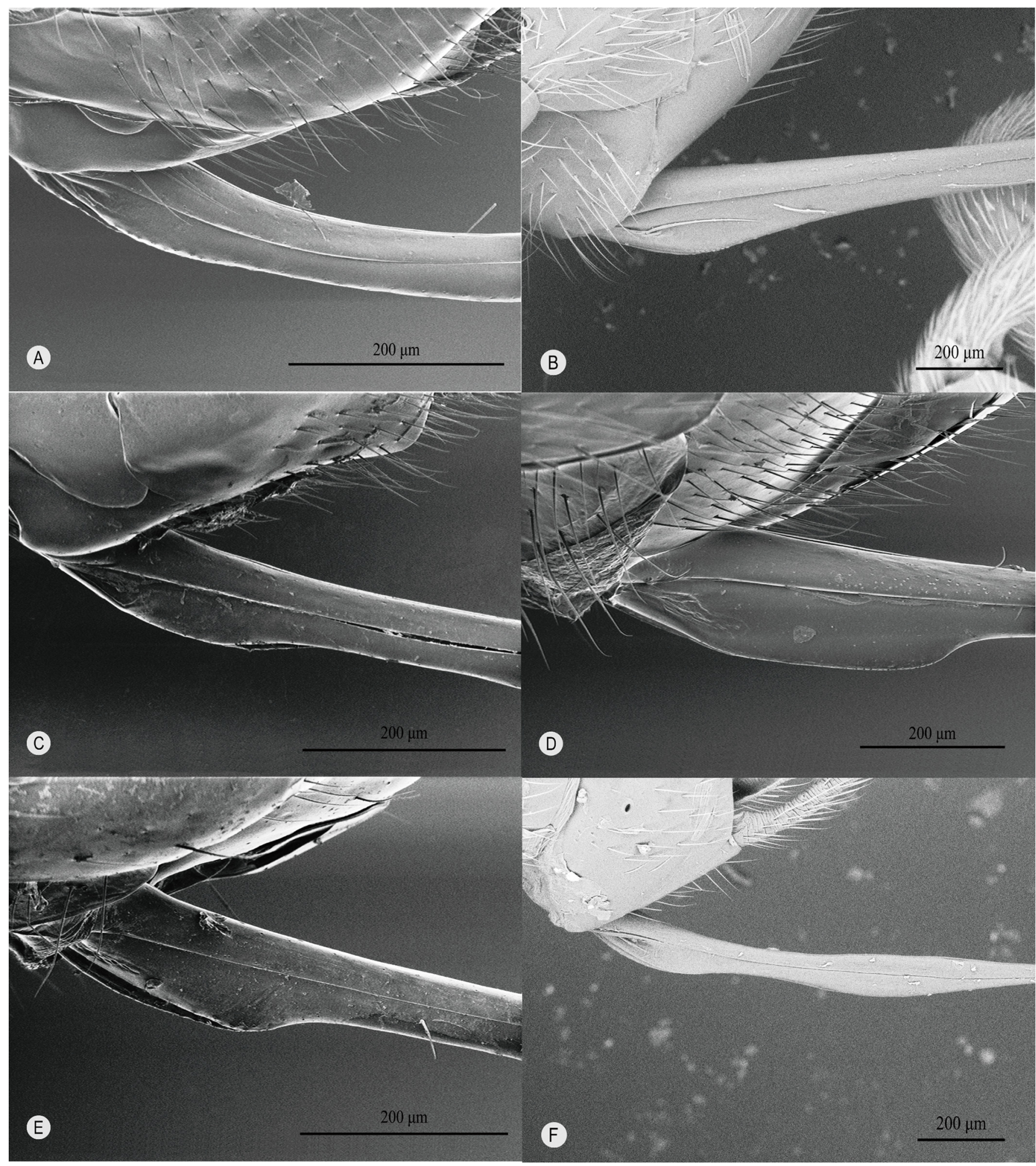

Figure 5. Ovipositor of clade II spp. with expansion near its proximal end. A Acrodactyla takewakii (Uchida, 1927) [134], B Eriostethus rufus, C Megaetaira varicarinata, D Reclinervellus tuberculatus, E Sinarachna sp., F Zatypota maculata.

lower inset, 3B-a, 5). Only in Oxyrrhexis (Fig. 6A), Chablisea (Fig. 6B) and Aravenator kamijoi Momoi, 1973 [91] (Fig. 6C) of clade II is this expansion at least superficially lacking (see $[41,82,102])$. Polysphincta has a rather weak expansion (Fig. 6D) in comparison with other clade II genera.

\section{Taxonomy of the hosts}

When known hosts for the genera of clade I including the new hosts discovered by us (for Zabrachypus and Piogaster), and the hosts for clade II (Table 1) are mapped 


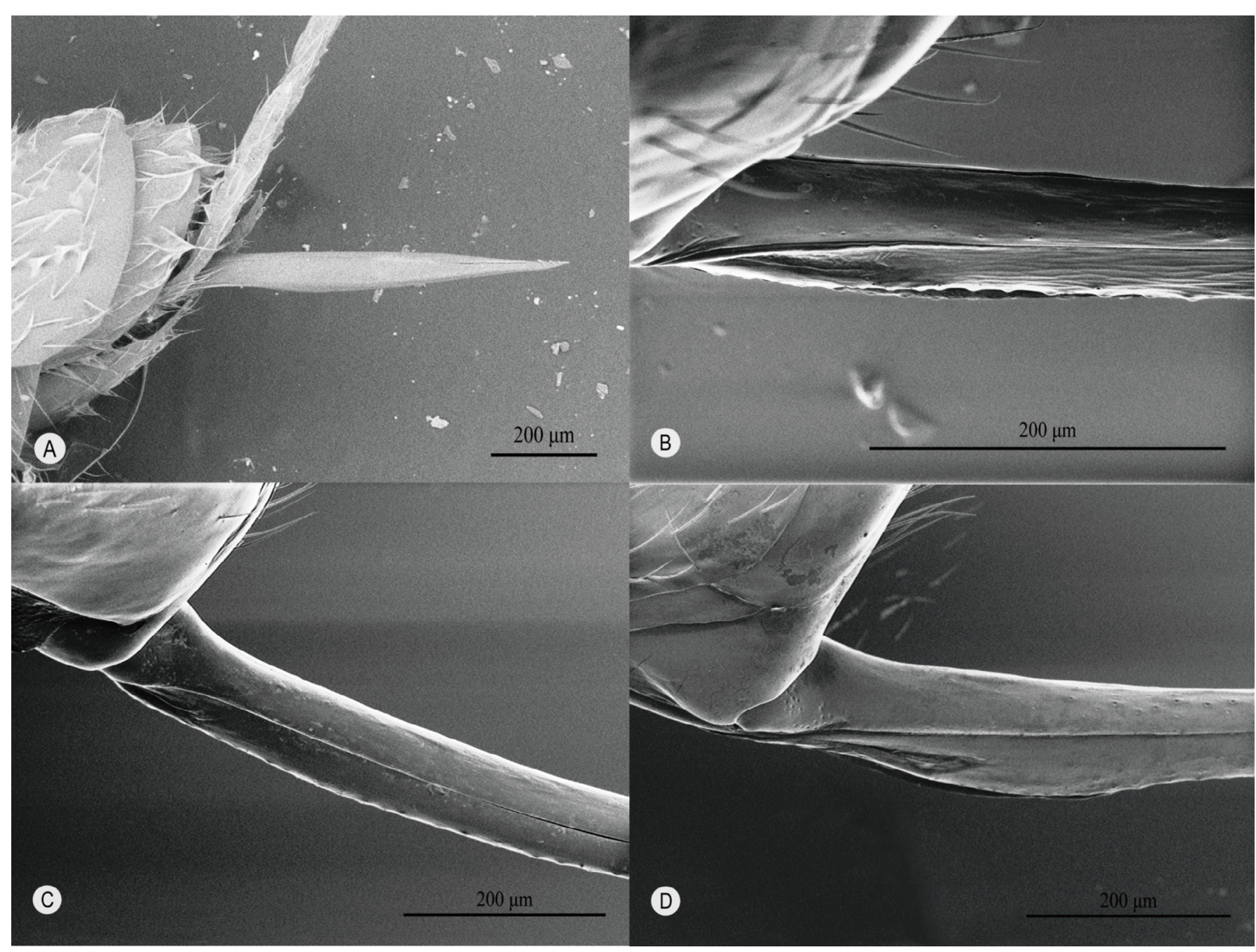

Figure 6. Ovipositor of clade II spp. with little or no expansion near its proximal end. A Oxyrrhexis carbonator, B Chablisea sp., C Aravenator kamijoi, D Polysphincta rufipes.

onto the most recent phylogeny of spiders [29,44,143], it is evident that the two polysphinctine clades use phylogenetically different groups of hosts. Clade I utilises both cursorial and ground-web building spiders exclusively of the RTAclade (Figs. 2A, 3A-e), plus the superfamily Titanoecoidea constituting an immediate outgroup of the RTA-clade [143], while clade II taxa attack aerial-web weaving spiders, of which all but a few (Dictynidae, see Discussion) belong to the superfamily Araneoidea (Figs. 2B, 3B-e).

\section{Discussion}

We have discovered that there are two clearly different oviposition stances in the polysphinctines, which we have called the dorsal-press and the ventral-press, reflecting which side of the ovipositor is in contact with the host. The former was previously unknown. We have also found that the different stances are linked to the phylogeny of the wasps, and additionally that the two stances clearly correlate with egg placement (and thus also larval development site), ovipositor morphology, place of egg expulsion, and finally with host taxonomy.
We posit that the dorsal-press, our newly-discovered oviposition stance used by polysphinctines of clade I only, which is the group regarded as the more ancestral [86], indicates an early evolutionary path of spider-ectoparasitism in comparison with that of clade II, in which species use the ventral-press.

The arguments advanced by Matsumoto [86] for regarding clade I as the more ancestral of the two major clades are accepted here, with some additional supporting observations. The genus Tromatobia, one of the immediate outgroups in Matsumoto's analysis, mainly uses eggsacs of Araneoidea [4,5,21,28,34,36,37,46,63,84,92,96,103, $118,132,137]$ (more rarely other groups $[4,36,37,64])$ that are either unguarded or, if guarded, the parasitoid does not envenomate let alone consume the female spider. In fact, as far as is known, it has no adverse interaction with the spider itself. These Araneoidea do not have a role as hosts of clade I polysphinctines but are the almost invariable hosts of clade II polysphinctines. However, there seems little in the biology of Tromatobia to suggest that it is close to the ancestry of clade II polysphinctines. On the other hand, the main hosts of Zaglyptus (the other immediate 
outgroup in Matsumoto's analysis) are in concealed eggnests with a guarding female in RTA-clade families such as Clubionidae, Eutichuridae and Salticidae [4,34,36,37, $69,70,92,95$ ] (rarely using hosts outside the RTA-clade such as Araneidae, Theridiidae and Tetragnathidae [4,36, $37]$ ), and the female is not only stung and permanently immobilised prior to oviposition but also at least partly consumed by the ensuing progeny [70,95] and, perhaps most significantly, the guarding spider will be consumed if she is still gravid when paralysed [95]. Thus, the closest biology, host associations, and degree of physical contact exhibited by known taxa parasitising spider egg-sacs or egg-nests involves RTA-clade hosts which are attacked in more or less concealed sites. This strongly suggests that these hosts will be involved in the ancestry of the polysphinctines as a whole, such that clade I is likely to be the more ancestral of the two clades. Despite the finding by Matsumoto [86] that in his phylogeny the single included species of Clistopyga fell outside the clade representing the polysphinctines + the two genera included in his analysis (Tromatobia and Zaglyptus) that use spider egg-sacs or egg-nests, it seems possible that a reappraisal of the position of Clistopyga may help to elucidate the origin of the polysphinctines. In this case, clade I would again be indicated as the more ancestral. This is because one species of Clistopyga is known to be a solitary idiobiont ectoparasitoid of adult/subadult Salticidae (in the RTA-clade) alone in its nest [42], while others have been reared in small broods from concealed nests of the RTA-clade Clubionidae and the more ancestral [143] and biologically similar (ground and rock-fissure tube-web $[10,15]$ ) Segestriidae containing egg-sacs within which they appeared to have fed $[36,94]$.

The dorsal-press of clade I is linked to the following: 1) oviposition on the cephalothorax of the host (Fig. 2A), 2) base of lower valves of the ovipositor simple (Figs. 1 upper inset, 3A-a, 4), 3) egg expulsion along the middle part of the ventral side of the ovipositor (Fig. 3A-b), and 4) utilisation of cursorial or ground-web weaving hosts belonging to the RTA-clade of spiders and its immediate outgroup (Table 1, Figs. 2A, 3A-e). The ventral-press of clade II is linked to $\mathbf{1}$ ) oviposition on the abdomen of the host (Fig. 2B), 2) expanded base of the lower valves of the ovipositor (Figs. 1 lower inset, 3B-a, 5), 3) egg expulsion from the base of the ventral side of the ovipositor (Fig. 3Bb), and 4) utilisation of aerial-web weaving hosts (Figs. 2B, 3B-e) that, with only a few exceptions, belong to the spider superfamily Araneoidea (Table 1).

The oviposition behaviour (as opposed to mere egg placement, which is very much better observed) for species of four genera in clade I, documented by us, and additionally Schizopyga illustrated by Matsumoto [86], has previously not been known. However, the oviposition behaviour in clade II has already been seen in three genera (Table 1). Additionally, the movement of the metasoma during oviposition in clade II had not been thoroughly described before.

Several species of clade II are already known not to expel the egg from the tip of the ovipositor (see [127];
Figs. 2B, 3B-b, S2). Although the eggs had previously been considered to be expelled from the genital opening (= below the base of the ovipositor, near the tip of metasoma) $[30,87,127]$, we have seen in several species that they are actually expelled from the base of the ovipositor (Figs. 2B, 3B-b, S2). This is not easily seen and we thus suspect that the interpretations of previous observations could be wrong and that all members of clade II actually expel the egg from the base of the ovipositor, not from the genital opening (unlike e.g. Aculeata). Eggs are expelled from the expansion at the proximal end of the ovipositor's lower valves (Fig. 3B-b), seemingly an autapomorphy of clade II, indicating a potential functional relationship between this modification and the ventralpressing behaviour (Fig. 3B-c). For example, in whatever way it is mechanically involved in the expulsion of the egg and/or adhesive material, the expansion at the proximal end may have a sensory function facilitating exact egg placement or simply a role of steadying the ovipositor onto the spider's skin while the egg is laid.

The egg expulsion along the middle part of the ovipositor reported here for members of clade I has not previously been documented in polysphinctines. We have clearly seen this in B. nikkoensis and in Piogaster sp., and our further incomplete observations (I. pictifrons and Zabrachypus sp.) suggest that it is likely to be the case in the other genera of clade I as well.

There are also noteworthy differences between the two clades ecologically. We can show that the two clades use phylogenetically different groups of hosts with partly distinctly different ecology. Clade I utilises both cursorial (hunting without a web but sometimes with a silken chamber for resting or egg-laying [cf. Fig. 3 in 15]) and ground-web building spiders exclusively of the RTA-clade and its immediate outgroup (Titanoecidae). Conversely, clade II attacks aerial-web weaving spiders mostly of the superfamily Araneoidea. These two spider groups form major distinct lineages within Entelegynae, which is hyperdiverse and the most derived monophyletic group, i.e. comprising the two major lineages (RTA-clade and Araneoidea) with several subclades [29,44,143].

Polysphinctine clades I and II apparently separated through a host shift, and many well-preserved characters are linked to oviposition and immature development. Parasitism of non-aerial-web weaving spiders, i.e. the RTA-clade (Figs. 2A, 3A-e), presumably practised by the first true polysphinctines, is evidently connected with the exclusive use of the cephalothorax as oviposition site where larval development commences, although after substantial growth and when the host is quiescent in its retreat, the larva also feeds from and consumes the abdomen [cf. Fig. 2a in 85]. Likewise the final instar larva of clade II also feeds from the cephalothorax of its recently killed host [30]. Despite the resulting larva then being faced with arguably a tougher pabulum than might be provided by the softer tissues of the host's abdomen, one possible reason for the use of the cephalothorax instead of the abdomen in clade I is that the egg and larva would be more exposed to physical damage on the abdomen than in 
a lower position on the carapace of RTA-spiders actively running on the plane and hiding in small crevices or in a thin tubular retreat, even in RTA web-weavers (e.g. Agelenidae). An obvious general need for accuracy in egg deposition might be served well by using the orientation of the ovipositor over a substantial part of its length as a guiding device, adequately facilitating oviposition onto the relatively flat surface of the carapace. Also, visibility of the oviposition site (Fig. 2A) would be aided by the stance adopted for the dorsal-press.

On the other hand, aerial-web weaving host spiders used by clade II (mainly Araneoidea; Figs. 2B, 3B-e) usually settle in or on their webs, probably causing less risk of physical damage to a polysphinctine egg or larva by strenuous movement. This also opens up easier access to these softer and arguably more palatable or nutritious tissues for the larva. In addition, these spiders typically droop from their own threads after subjugation and the parasitoid hangs from the spider's abdomen via its fore/ middle legs (Figs. 2B, 3B). In such unstable situations, the ventral-press might facilitate egg deposition onto a distant and less visible side of the abdomen (Figs. 2B, 3B), with a consequent transfer of the site for egg expulsion and an expansion of the ovipositor at its proximal end.

Once the major host shift occurred between clades I and II, the two opposite oviposition stances seem to be largely fixed for coping with each host spider group. At least on the basis of the extant biota, the utilisation of Araneoidea appears to have promoted a stronger radiation and/or survival among clade II (18 genera, >200 species). This is probably associated with feeding advantages and easier location of the conspicuous webs of Araneoidea than is seen among clade I ( 7 genera, $<50$ species), despite the greater species-richness of the RTA-clade $(24,681$ species in 2,073 genera [144], 43 families of eight higher groups [143]) than Araneoidea (12,394 species in 1,130 genera [144], 17 families [29]). However, an apparently fixed hostgroup reversal onto an RTA-clade host, Dictyna spp. (Dictynidae), by a species of the clade II polysphinctine Zatypota anomala (Holmgren, 1860) [65] has taken place $[67,75,140]$, but retaining typical Zatypota egg placement. This colonisation of an RTA-clade host presumably occurred because Dictyna inhabits aerial parts of plants (rather than being ground-dwelling) and produces webs similar to those of the theridiid (Araneoidea) hosts parasitised by most Zatypota species in similar habitats.

Any possible relationship between the position of the egg on the abdomen, the exact oviposition process, and the variable size and nature of the ventral expansion at the proximal end of the ovipositor among clade II taxa (weak in Polysphincta (Fig. 6D); apparently absent in Oxyrrhexis (Fig. 6A) and in two genera of completely unknown biology, Chablisea (Fig. 6B) and Aravenator (Fig. 6C)) is beyond the scope of this paper, but might be a worthwhile and revealing study.

Acknowledgements. This work was supported by JSPS KAKENHI No. JP16K18620, JSPS Research Fellowships for Young Scientists No. JP17J40065 and The Swedish Cultural
Foundation in Finland No. 15/0347, 17/0691. We thank Kyohei Watanabe (Kanagawa Prefectural Museum of Natural History) for a loan of ichneumonid specimens, Yuki G. Baba (NARO) for valuable comments on spider phylogeny, Yuya Suzuki (Tsukuba University) for helpful suggestions about spider morphology, and Gavin Broad and two other (anonymous) reviewers for constructive criticism.

\section{Conflict of interest}

The authors declare that they have no competing or financial interests.

\section{Supplementary Material}

Figure S1. Metasoma movement during the dorsal-press by Brachyzapus nikkoensis.

Figure S2. Metasoma movement during the ventral-press by Zatypota albicoxa.

The Supplementary Material is available at https:// www.parasite-journal.org/10.1051/parasite/2018011/olm.

\section{References}

1. Agnarsson I, Coddington JA, Kuntner M. 2013. Systematics: progress in the study of spider diversity and evolution, in: Spider Research in the 21st Century, Penny D, Ed. Siri Scientific Press: Manchester, U. K. p. 58-111.

2. Aubert JF. 1958. Ichneumonide Pimpline d'un genre nouveau, espèce nouvelle, répandue sur le rivage méditerranéen. Bulletin de la Société Entomologique de Mulhouse, 1958, 79-80.

3. Aubert JF. 1965. Ichneumonides d'Europe appartenant à dix espèces nouvelles et plusieurs genres nouveaux. Bulletin de la Société Entomologique de Mulhouse, 1965, 15-23

4. Austin AD. 1985. The function of spider egg sacs in relation to parasitoids and predators, with special reference to the Australian fauna. Journal of Natural History, 19(2), 359-376.

5. Auten M. 1925. Insects associated with spider nests. Annals of the Entomological Society of America, 18(2), 240-250.

6. Baltazar CR. 1964. Eriostethus Morley and a new polysphinctine genus (Ichneumonidae, Hymenoptera). Pacific Insects, 6(2), 388-401.

7. Barrantes G, Eberhard WG, Weng JL. 2008. Seasonal patterns of parasitism of the tropical spiders Theridion evexum (Araneae, Theridiidae) and Allocyclosa bifurca (Araneae, Araneidae) by the wasps Zatypota petronae and Polysphincta gutfreundi (Hymenoptera, Ichneumonidae). Revista de Biologia Tropical, 56(2), 749-754.

8. Barrantes G, Sandoval L, Hanson PE. 2017. Cocoon web induced by Eruga telljohanni (Ichneumonidae: Pimplinae) in Leucauge sp. (Tetragnathidae). Arachnology, 17(5), 245-247.

9. Barrantes G, Weng JL. 2007. Natural history, courtship, feeding behaviour and parasites of Theridion evexum (Araneae: Theridiidae). Arachnology, 14(2), 61-65.

10. Bee L, Oxford GS, Smith H. 2017. Britain's Spiders A Field Guide: Princeton University Press. 480 pp.

11. Belgers JDM, Zwakhals CJ, van Helsdingen PJ. 2013. De bijzondere levensloop van de sluipwesp Acrodactyla quadrisculpta op de schaduwstrekspin Tetragnatha montana. Nederlandse Faunistische Mededelingen, 39, 1-6. 
12. Belshaw R, Grafen A, Quicke DLJ. 2003. Inferring life history from ovipositor morphology in parasitoid wasps using phylogenetic regression and discriminant analysis. Zoological Journal of the Linnean Society, 139(2), 213-228.

13. Blackledge TA, Scharff N, Coddington JA, Szuts T, Wenzel JW, Hayashi CY, Agnarsson I. 2009. Reconstructing web evolution and spider diversification in the molecular era. Proceedings of the National Academy of Sciences of the United States of America, 106(13), 52295234.

14. Bovee J, Leech R. 2014. Araneus gemmoides (Araneae, Araneidae) death by a parasitoid (Hymenoptera, Ichneumonidae). Bulletin of the Entomological Society of Canada, 46(2), 86-91.

15. Bradley RA, Buchanan S. 2012. Common Spiders of North America: University of California Press. $271 \mathrm{pp}$.

16. Brambila J, Porter CC. 2005. First records of Acrotaphus fuscipennis (Cresson) and of $A$. tibialis (Cameron) from the United States (Hymenoptera: Ichneumonidae). Insecta Mundi, 19(3), 151-157.

17. Brues CT, Richardson CH. 1913. Descriptions of new parasitic Hymenoptera from British Guiana. Bulletin of the American Museum of Natural History, 32, 485-503.

18. Brullé MA. 1846. Les Ichneumonides, in: Histoire Naturelle des Insectes. Hyménoptères, le Comte PM, Ed. Paris, France. p. 56-521.

19. Cambridge OP. 1882. External parasites of spiders. Entomologist, 15, 216.

20. Cameron P. 1883-1900. Biologia Centrali-Americana. Insecta. Hymenoptera. (Families Tenthredinidae Chrysididae) Vol. 1. London, U.K. 487 pp.

21. Carlson RW. 1979. Family Ichneumonidae, in: Catalog of Hymenoptera in America north of Mexico vol. 1, Krombein KV, Hurd Jr. PD, Smith DR, Burks BD, Eds. Smithsonian Institution Press: Washington, U. S. A. p. 315-741.

22. Coddington JA. 2005. Phylogeny and classification of spiders, in: Spiders of North America: An Identification Manual, Ubick D, Paquin P, Cushing PE, Roth V, Eds. American Arachnological Society: Ohio, U. S. A. p. 18-24.

23. Coddington JA, Levi HW. 1991. Systematics and evolution of spiders (Araneae). Annual Review of Ecology and Systematics, 22(1), 565-592.

24. Cresson ET. 1865. On the Hymenoptera of Cuba. Proceedings of the Entomological Society of Philadelphia, 4, 1-200.

25. Cresson ET. 1870. Descriptions of new species belonging to the subfamily Pimplariae found in America north of Mexico. Transactions of the American Entomological Society (Philadelphia), 3, 143-172.

26. Cushman RA. 1913. Biological notes on a few rare or little known parasitic Hymenoptera. Proceedings of the Entomological Society of Washington, 15, 153-161.

27. Cushman RA. 1926. Some types of parasitism among the Ichneumonidae. Proceedings of the Entomological Society of Washington, 28(2), 29-51.

28. De Santis L. 1967. Cata'logo de los himeno'pteros argentinos de la serie Parasitica, incluyendo Bethyloidea. Provincia de Buenos Aires, Publicación Comisio'n de Investigaciones Cienti'ficas: La Plata. 337 pp.

29. Dimitrov D, Benavides LR, Arnedo MA, Giribet G, Griswold CE, Scharff N, Hormiga G. 2017. Rounding up the usual suspects: a standard target-gene approach for resolving the interfamilial phylogenetic relationships of ecribellate orb-weaving spiders with a new family-rank classification (Araneae, Araneoidea). Cladistics, 33(3), 221-250.
30. Eberhard WG. 2000. The natural history and behavior of Hymenoepimecis argyraphaga (Hymenoptera: Ichneumonidae) a parasitoid of Plesiometa argyra (Araneae: Tetragnathidae). Journal of Hymenoptera Research, 9(2), 220-240.

31. Eberhard WG. 2010. New types of behavioral manipulation of host spiders by a parasitoid wasp. Psyche, Article ID 950614.

32. Eberhard WG. 2010. Recovery of spiders from the effects of parasitic wasps: implications for fine-tuned mechanisms of manipulation. Animal Behaviour, 79(2), 375-383.

33. Eberhard WG. 2013. The polysphinctine wasps Acrotaphus tibialis, Eruga ca. gutfreundi, and Hymenoepimecis tedfordi (Hymenoptera, Ichneumonidae, Pimplinae) induce their host spiders to build modified webs. Annals of the Entomological Society of America, 106(5), 652-660.

34. Finch O-D. 2005. The parasitoid complex and parasitoidinduced mortality of spiders (Araneae) in a Central European woodland. Journal of Natural History, 39(25), 2339-2354.

35. Fincke OM, Higgins L, Rojas E. 1990. Parasitism of Nephila clavipes (Araneae, Tetragnathidae) by an ichneumonid (Hymenoptera, Polysphinctini) in Panama. Journal of Arachnology, 18(3), 321-329.

36. Fitton MG, Shaw MR, Gauld ID. 1988. Pimpline ichneumon-flies Hymenoptera, Ichneumonidae (Pimplinae). Handbook for the Identification of British Insects, Eds. Barnard PC, Askew RR. London, U.K.: Royal Entomological Sciety of London. $110 \mathrm{pp}$.

37. Fitton MG, Shaw MR, Austin AD. 1987. The Hymenoptera associated with spiders in Europe. Zoological Journal of the Linnean Society, 90(1), 65-93.

38. Fritzén NR. 2005. Polysphincta nielseni (Hymenoptera, Ichneumonidae, Pimplinae) new to Finland. Memoranda Societas pro Fauna et Flora Fennica, 81(2), 49-51.

39. Fritzén NR. 2010. Natural history and description of Zatypota kerstinae sp.nov (Hymenoptera: Ichneumonidae) reared from Theridion palmgreni Marusik et Tsellarius (Araneae: Theridiidae) in Finland. Zootaxa, 2487, 52-60.

40. Fritzén NR. 2014. Two new species of the Polysphincta genus-group (Hymenoptera: Ichneumonidae: Pimplinae) reared from their spider (Araneae) hosts in Europe. Zootaxa, 3894(1), 117-130.

41. Fritzén NR, Fjellberg A. 2014. Natural history of Oxyrrhexis zephyrus sp. n. (Hymenoptera, Ichneumonidae), a parasitoid of Enoplognatha serratosignata (Araneae, Theridiidae), with notes on taxonomy and other host species of Oxyrrhexis. Arthropoda Selecta, 23(2), 135-144.

42. Fritzén NR, Sääksjärvi IE. 2016. Spider silk felting functional morphology of the ovipositor tip of Clistopyga sp. (Ichneumonidae) reveals a novel use of the hymenopteran ovipositor. Biology Letters, 12(8), 20160350.

43. Fritzén NR, Shaw MR. 2014. On the spider parasitoids Polysphincta longa Kasparyan and P. boops Tschek (Hymenoptera, Ichneumonidae, Pimplinae), with the first host records of $P$. longa. Journal of Hymenoptera Research, 39, 71-82.

44. Garrison NL, Rodriguez J, Agnarsson I, Coddington JA, Griswold CE, Hamilton CA, Hedin M, Kocot KM, Ledford JM, Bond JE. 2016. Spider phylogenomics: untangling the Spider Tree of Life. PeerJ, 4, e1719.

45. Gauld ID. 1984. The Pimplinae, Xoridinae, Acaenitinae and Lycorininae of Australia. Bulletin of the British Museum (Natural History) Entomology, 49(4), 235-339.

46. Gauld ID. 1991. The Ichneumonidae of Costa Rica, 1. Memoirs of the American Entomological Institute 47. Gainesville, U.S.A.: The American Entomological Institute. 589 pp. 
47. Gauld ID. 2000. The re-definition of pimpline genus Hymenoepimecis (Hymenoptera: Ichneumonidae) with a description of a plesiomorphic new Costa Rican species. Journal of Hymenoptera Research, 9, 213-219.

48. Gauld ID, Dubois J. 2006. Phylogeny of the Polysphincta group of genera (Hymenoptera: Ichneumonidae; Pimplinae): a taxonomic revision of spider ectoparasitoids. Systematic Entomology, 31(3), 529-564.

49. Gauld ID, Ugalde Gómez JA. 2002. Appendix 1. Subfamily Pimplinae. The Ichneumonidae of Costa Rica, 4. Memoirs of the American Entomological Institute, 66, 1-768.

50. Godfray HCJ. 1994. Parasitoids: Behavioral and Evolutionary Ecology. Princeton, U.S.A.: Princeton University Press. 473 pp.

51. Gonzaga MO, Loffredo APS, Penteado-Dias AM, Cardoso JCF. 2016. Host behavior modification of Achaearanea tingo (Araneae: Theridiidae) induced by the parasitoid wasp Zatypota alborhombarta (Hymenoptera: Ichneumonidae). Entomological Science, 19(2), 133-137.

52. Gonzaga MO, Moura RR, Pêgo PT, Bang DL, Meira FA. 2015. Changes to web architecture of Leucauge volupis (Araneae: Tetragnathidae) induced by the parasitoid Hymenoepimecis jordanensis (Hymenoptera: Ichneumonidae). Behaviour, 152(2), 181-193.

53. Gonzaga MO, Sobczak JF. 2007. Parasitoid-induced mortality of Araneus omnicolor (Araneae, Araneidae) by Hymenoepimecis sp. (Hymenoptera, Ichneumonidae) in southeastern Brazil. Naturwissenschaften, 94(3), 223-227.

54. Gonzaga MO, Sobczak JF, Penteado-Dias AM, Eberhard WG. 2010. Modification of Nephila clavipes (Araneae Nephilidae) webs induced by the parasitoids Hymenoepimecis bicolor and $H$. robertsae (Hymenoptera Ichneumonidae). Ethology Ecology \& Evolution, 22(2), 151-165.

55. Gordh G. 1971. A biological note on Hymenoepimecis wiltii and its host, Neoscona arabesca. Journal of the Kansas Entomological Society, 44(2), 171-172.

56. Gravenhorst JLC. 1807. Vergleichende Übersicht des Linneischen und einiger neurern zoologischen Systeme, nebst dem eingeschalteten Verzeichnisse der zoologischen Sammlung des Verfasser und den Beschreibungen neuer Thierarten, die in derselben vorhanden sind. Göttingen. 476 pp.

57. Gravenhorst JLC. 1820. Monographia Ichneumonum Pedemontanae Regionis. Memorie della Reale Academia dell Scienze di Torino, 24, 275-388.

58. Gravenhorst JLC. 1829. Ichneumonologia Europaea. Pars III. Vratislaviae. 1097 pp.

59. Griswold CE. 1999. Towards a phylogeny of entelegyne spiders (Araneae, Araneomorphae, Entelegynae). Journal of Arachnology, 27, 53-63.

60. Griswold CE, Ramirez MJ, Coddington JA, Platnick NI. 2005. Atlas of Phylogenetic Data for Entelegyne Spiders (Araneae: Araneomorphae: Entelegynae) with Comments on Their Phylogeny. Proceedings of the California Academy of Sciences. Vol. 56: California Academy of Sciences. $324 \mathrm{pp}$.

61. Hahn CW. 1833. Nürnberg, Erster Band, Zweiter Band, in: Die Arachniden. p. 77-129; 1-16.

62. Haliday AH. 1838. Descriptions of new British insects, indicated in Mr. Curtis's guide. Annals of Natural History, 2, 112-121.

63. Hashimoto R. 1963. Six hymenopterous parasites of the spiders. Acta Arachnologica, 18(2), 27-29 (in Japanese).

64. He JH, Chen XX, Ma Y. 1996. Hymenoptera: Ichneumonidae. Economic Insect Fauna of China. Vol. 51. Beijing, China: Science Press. 697 pp. (in Chinese).
65. Holmgren AE. 1860. Försök till uppställning och beskrifning af Sveriges Ichneumonider. Tredje Serien. Fam. Pimplariae. (Monographia Pimplariarum Sueciae). Vetenskapsakademiens Handlingar, (B), 3(10), 1-76.

66. Howard LO. 1888. Further concerning external spider parasites. Insect Life, 1, 106-107.

67. Howard LO. 1892. The hymenopterous parasites of spiders. Proceedings of the Entomological Society of Washington, 2, 290-302.

68. Howell JO, Pienkowski RL. 1972. Notes on the biology of a spider parasite Colpomeria kincaidii (Hymenoptera: Ichneumonidae). Entomophaga, 17(1), 5-7.

69. Iwata K. 1942. Biology of some Japanese Polysphincta. Mushi, 14, 98-102.

70. Iwata K. 1963. Biology of an ectoparasitoid of Clubiona japonicola Boesnberg et Strand, Zaglyptus iwatai Uchida. Plant Protection Bulletin, 5(3), 147-155.

71. Kasparyan DR. 1976. Review of Ichneumonids of the tribe Polysphinctini and Poemeniini (Hymenoptera, Ichneumonidae) of the Far East (in Russian). Trudy Zoologicheskogo Instituta, 67, 68-89.

72. Kloss TG, Gonzaga MO, Roxinol JAM, Sperber CF. 2016. Attack behavior of two wasp species of the Polysphincta genus group (Hymenoptera, Ichneumonidae) on their orbweaver spider hosts (Araneae, Araneidae). Journal of Insect Behavior, 29(3), 315-324.

73. Kloss TG, Gonzaga MO, Roxinol JAM, Sperber CF 2016. Host behavioural manipulation of two orb-weaver spiders by parasitoid wasps. Animal Behaviour, 111, 289296.

74. Koch CL. 1841. Die Arachniden. Nürnberg, Achter Band. $131 \mathrm{pp}$.

75. Korenko S. 2017. First record from Italy of Zatypota anomala (Ichneumonidae, Ephialtini), a parasitoid of the cribellate spider Dictyna pusilla (Araneae, Dictynidae). Arachnologische Mitteilungen, 54, 1-4.

76. Korenko S, Hamouzová K, Kysilková K, Kolárová M, Kloss TG, Takasuka K, Pekár S. 2018. Divergence in host utilisation by two spider ectoparasitoids within the genus Eriostethus (Ichneumonidae, Pimplinae). Zoologischer Anzeiger, 272, 1-5.

77. Korenko S, Korenková B, Satrapová J, Hamouzová K, Belgers D. 2015. Modification of Tetragnatha montana (Araneae, Tetragnathidae) web architecture induced by larva of the parasitoid Acrodactyla quadrisculpta (Hymenoptera, Ichneumonidae, Polysphincta genus-group). Zoological Studies, 54(1), 50

78. Korenko S, Kysilková K, Cernecká L'. 2017. Further record of two spider-parasitoids of the genus Polysphincta (Hymenoptera, Ichneumonidae, Ephialtini) from Central Europe, with notes on their host interactions. Arachnologische Mitteilungen, 54, 28-32.

79. Korenko S, Potopová V, Satrapová J, Pekár S. 2016. Life history of the spider parasitoid Zatypota percontatoria (Hymenoptera: Ichneumonidae). Entomological Science, 19(2), 104-111.

80. Korenko S, Satrapová J, Zwakhals K. 2015. Manipulation of araneid spider web architecture by the polysphinctine parasitoid Zatypota picticollis (Hymenoptera: Ichneumonidae: Pimplinae). Entomological Science, 18(3), 383-388.

81. Kusigemati K. 1985. A new species of the genus Piogaster Perkins from Japan (Hymenoptera, Icuneumonidae). Kontyû, 53(4), 583-586.

82. Liu JX, He JH, Chen XX. 2009. Two new species of genus Chablisea Gauld et Dubois, 2006 (Hymenoptera: Ichneumonidae: Pimplinae) from China. Biologia, 64(6), 11651169 
83. Loffredo APS, Penteado-Dias AM. 2009. New species of Hymenoepimecis Viereck (Hymenoptera, Ichneumonidae, Pimplinae) from Brazilian Atlantic forest. Revista Brasileira de Entomologia, 53(1), 11-14.

84. Marshall TA. 1892. Énumerations de quelques Hyménoptères du Venezuela. Bulletin de la Société Entomologique de France, 61, 60-76.

85. Matsumoto R. 2008. "Veils" against predators: modified web structure of a host spider induced by an ichneumonid parasitoid, Brachyzapus nikkoensis (Uchida) (Hymenoptera). Journal of Insect Behavior, 22(1), 39-48.

86. Matsumoto R. 2016. Molecular phylogeny and systematics of the Polysphincta group of genera (Hymenoptera, Ichneumonidae, Pimplinae). Systematic Entomology, 41 (4), 854-864.

87. Matsumoto R, Konishi K. 2007. Life histories of two ichneumonid parasitoids of Cyclosa octotuberculata (Araneae): Reclinervellus tuberculatus (Uchida) and its new sympatric congener (Hymenoptera: Ichneumonidae: Pimplinae). Entomological Science, 10(3), 267-278.

88. Matsumoto R, Takasuka K. 2010. A revision of the genus Zatypota Förster of Japan, with descriptions of nine new species and notes on their hosts (Hymenoptera: Ichneumonidae: Pimplinae). Zootaxa, 2522, 1-43.

89. Miller JA, Belgers JD, Beentjes KK, Zwakhals K, van Helsdingen P. 2013. Spider hosts (Arachnida, Araneae) and wasp parasitoids (Insecta, Hymenoptera, Ichneumonidae, Ephialtini) matched using DNA barcodes. Biodiversity Data Journal, 1, e992.

90. Miller JA, Carmichael A, Ramirez MJ, Spagna JC, Haddad CR, Rezac M, Johannesen J, Kral J, Wang XP Griswold CE. 2010. Phylogeny of entelegyne spiders: affinities of the family Penestomidae new rank), generic phylogeny of Eresidae, and asymmetric rates of change in spinning organ evolution (Araneae, Araneoidea, Entelegynae). Molecular Phylogenetics and Evolution, 55(3), 786-804.

91. Momoi S. 1973. Ergebnisse der zoologischen Forschungen von Dr. Z. Kaszab in der Mongolei. 331. Einige mongolischen Arten der Unterfamilien Ephialtinae und Xoridinae (Hymenoptera: Ichneumonidae). Folia Entomologica Hungarica, 26(Suppl.), 219-239.

92. Nielsen E. 1923. Contributions to the life history of the pimpline spider parasites (Polysphincta, Zaglyptus, Tromatobia) (Hym. Ichneum.). Entomologiske Meddelelser, 14, 137-205.

93. Nielsen E. 1928. A supplementary note upon the life histories of the Polysphinctas (Hym. Ichneum.). Entomologiske Meddelelser, 16, 152-155.

94. Nielsen E. 1929. A second supplementary note upon the life histories of polysphinctas (Hym. Ichneum.). Entomologiske Meddelelser, 16, 366-368.

95. Nielsen E. 1935. A third supplementary note upon the life histories of polysphinctas (Hym. Ichneum.). Entomologiske Meddelelser, 19, 191-215.

96. Nielsen E. 1937. A fourth supplementary note upon the life histories of polysphinctas (Hym. Ichneum.). Entomologiske Meddelelser, 20, 25-28.

97. Oliger TI. 1983. New species of spider families (Pholcidae, Clubionidae, Agelenidae) from the Lazovsky State Reserve (in Russian). Zoologicheskiǔ Zhurnal, 62, 627-629.

98. Pádua DG, Salvatierra L, Sobczak JF, Oliveira ML. 2016. Parasitism of Hymenoepimecis manauara Pádua \& Oliveira (Hymenoptera: Ichneumonidae: Pimplinae) on Leucauge henryi Mello-Leitão (Araneae: Tetragnathidae) in Brazilian Amazonian. Biodiversity Data Journal, 4, e11219.
99. Paik KY. 1985. Three new species of clubionid spiders from Korea. Korean Arachnology, 1(1), 1-11.

100. Panzer GWF. 1797. Fauna insectorum germaniae initia. Deutschlands Insekten. Heft, 40, Araneae, fol. 22.

101. Panzer GWF. 1800. Faunae Insectorum Germanicae. Heft, 79, 8-14.

102. Pham NT, Broad GR, Matsumoto R, Wägele WJ. 2011. Two new species of the genus Chablisea Gauld et Dubois (Hymenoptera: Ichneumonidae: Pimplinae) from Vietnam. Biologia, 66(6), 1134-1139.

103. Quicke DLJ. 1988. A new host record for Tromatobia notator (Hym., Ichneumonidae). Entomologist's Monthly Magazine, 124, 164.

104. Quicke DLJ. 1991. Ovipositor mechanics of the braconine wasp genus Zaglyptogastra and the ichneumonid genus Pristomerus. Journal of Natural History, 25(4), 971-977.

105. Quicke DLJ. 2015. The Braconid and Ichneumonid Parasitoid Wasps: Biology, Systematics, Evolution and Ecology: Willey Blackwell. 681 pp.

106. Quicke DLJ, Fitton MG. 1995. Ovipositor steering mechanisms in parasitic wasps of the families Gasteruptiidae and Aulacidae (Hymenoptera). Proceedings of the Royal Society B: Biological Sciences, 261(1360), 99103.

107. Quicke DLJ, Fitton MG, Tunstead JR, Ingram SN, Gaitens PV. 1994. Ovipositor structure and relationships within the Hymenoptera, with special reference to the Ichneumonoidea. Journal of Natural History, 28(3), 635-682.

108. Quicke DLJ, Laurenne NM, Fitton MG, Broad GR. 2009. A thousand and one wasps: a $28 \mathrm{~S}$ rDNA and morphological phylogeny of the Ichneumonidae (Insecta: Hymenoptera) with an investigation into alignment parameter space and elision. Journal of Natural History, 43(23-24), 1305-1421.

109. Quicke DLJ, Le Ralec A, Vilhelmsen L. 2000. Ovipositor structure and function in the parasitic Hymenoptera with an exploration of new hypotheses. Rendiconti, 47 (197-239).

110. Roman A. 1923. Nya Polysphincta-former ur de Nielsen'ska kläckningarne. Entomologiske Meddelelser, 14, 206210.

111. Schmitt M, Richter D, Göbel D, Zwakhals K. 2012. Beobachtungen zur Parasitierung von Radnetzspinnen (Araneidae) durch Polysphincta rufipes (Hymenoptera: Ichneumonidae). Arachnologische Mitteilungen, 44, 1-6.

112. Shaw MR. 1998. Hyménoptères européens en particulier les Polysphinctini dont les larves se nourrissent d'araignées. Connaissance des Invertébrés Série Arachnides, 3, 14-40.

113. Shaw MR. 2006. Notes on British Pimplinae and Poemeniinae (Hymenoptera: Ichneumonidae), with additions to the British list. British Journal of Entomology and Natural History, 19, 217-238

114. Shaw MR, Wahl DB. 2014. Biology, early stages and description of a new species of Adelognathus Holmgren (Hymenoptera: Ichneumonidae: Adelognathinae). Zootaxa, 3884(3), 235-252.

115. Sobczak JF, Loffredo APS, Camargo LF, Penteado-Dias AM. 2012. Hymenoepimecis neotropica (Brues \& Richardson) (Hymenoptera, Ichneumonidae, Pimplinae) parasitoid of Araneus omnicolor (Keyserling) (Araneae, Araneidae): first host record and new occurrence to Brazil. Revista Brasileira de Entomologia, 56(3), 390-392.

116. Sobczak JF, Loffredo APS, Penteado-Dias AM. 2012. Parasitism on Araneus venatrix (Koch, 1838) (Araneae: Araneidae) by Hymenoepimecis silvanae Loffredo and Penteado-Dias, 2009 (Ichneumonidae, Pimplinae) with description of male of the wasp. Brazilian Journal of Biology, 72(1), 221-223. 
117. Sobczak JF, Loffredo APS, Penteado-Dias AM, Gonzaga MO. 2009. Two new species of Hymenoepimecis (Hymenoptera: Ichneumonidae: Pimplinae) with notes on their spider hosts and behaviour manipulation. Journal of Natural History, 43(43-44), 2691-2699.

118. Sobczak JF, Loffredo APS, Sobczak JCMSM. 2012. First record of egg sac predation of the wasp Tromatobia sp. Foster, 1869 (Hymenoptera: Ichneumonidae) upon Araneus omnicolor (Keyserling, 1893) (Araneae: Araneidae). Revista Ibérica de Aracnología, 20, 113-115.

119. Sobczak JF, Messas YF, Pádua DG. 2017. Parasitism of Zatypota riverai Gauld (Hymenoptera: Ichneumonidae: Pimplinae) on Anelosimus baeza Agnarsson (Araneae: Theridiidae) in northeast Brazil, with a description of the male. Zootaxa, 4247(1), 78-82.

120. Sobczak JF, Pádua DG, Costa LFA, Carvalho JLVR, Ferreira JPS, Sobczak JCMSM, Messas YF. 2018. The parasitoid wasp Eruga unilabiana Pádua \& Sobczak, sp. nov. (Hymenoptera: Ichneumonidae) induces behavioral modification in its spider host. Entomological Science, 21(1), 59-65.

121. Sobczak JF, Villanueva-Bonilla GA, Pádua DG, Messas YF. 2017. The wasp Flacopimpla varelae Gauld (Ichneumonidae: Pimplinae), parasitoid of the spider Achaearanea tingo Levi (Theridiidae: Theridiinae), with description of the male wasp. Zootaxa, 4365(5), 594-599.

122. Spagna JC, Gillespie RG. 2008. More data, fewer shifts: molecular insights into the evolution of the spinning apparatus in non-orb-weaving spiders. Molecular Phylogenetics and Evolution, 46(1), 347-368.

123. Taczanowski L. 1866. Spis pajaków zebranych w okolicach Warszawy w ciaggu roku 1865. Wykaz Szkoly Glownej Warszawskiego, 5, 1-14

124. Takasuka K, Korenko S, Kysilková K, Štefánik M, Cernecká L', Mihál I, Dolejš P, Holý K. 2017. Host utilization of koinobiont spider-ectoparasitoids (Ichneumonidae, Ephialtini, Polysphincta genus-group) associated with Cyclosa spp. (Araneae, Araneidae) across the Palaearctic. Zoologischer Anzeiger, 267, 8-14.

125. Takasuka K, Matsumoto R. 2011. Infanticide by a solitary koinobiont ichneumonid ectoparasitoid of spiders. Naturwissenschaften, 98(6), 529-536.

126. Takasuka K, Matsumoto R. 2011. Lying on the dorsum: unique host-attacking behaviour of Zatypota albicoxa (Hymenoptera, Ichneumonidae). Journal of Ethology, 29 (2), 203-207.

127. Takasuka K, Matsumoto R, Ohbayashi N. 2009. Oviposition behavior of Zatypota albicoxa (Hymenoptera, Ichneumonidae), an ectoparasitoid of Achaearanea tepidariorum (Araneae, Theridiidae). Entomological Science, 12(3), 232-237.

128. Takasuka K, Yasui T, Ishigami T, Nakata k, Matsumoto R, Ikeda K, Maeto K. 2015. Host manipulation by an ichneumonid spider-ectoparasitoid that takes advantage of preprogrammed web-building behaviours for pupal protection. Journal of Experimental Biology, 218, 23262332 .
129. Thomson CG. 1877. XXVII. Bidrag till kännedom om Sveriges Pimpler. Opuscula Entomologica, Lund, 8, 732777 .

130. Thorell T. 1875. Descriptions of several European and North African spiders. Bihang till Kongliga Svenska Vetenskaps-Akademiens Handlingar, 13(5), 1-203.

131. Townes H. 1969. The Genera of Ichneumonidae, Part 1. Memoirs of the American Entomological Institute 11. Gainesville, U.S.A.: The American Entomological Institute. $300 \mathrm{pp}$.

132. Townes H, Townes M. 1960. Ichneumon-flies of American North of Mexico 2. Subfamily Ephialtinae, Xoridinae, Acaenitinae. United States National Museum Bulletin, 216(2), 1-676.

133. Tschek C. 1869. Beiträge zur Kenntniss der österreichischen Pimplarien. Verhandlungen der Zoologisch-Botanischen Gesellschaft in Wien, 18(1868), 269-280.

134. Uchida T. 1927. Zwei neue Schmarotzerhymenopteren der Spinnen. Insecta Matsumurana, 1(4), 171-174.

135. Uchida T. 1928. Dritter Beitrag zur IchneumonidenFauna Japans. Journal of the Faculty of Agriculture, Hokkaido Imperial University, 25, 1-115.

136. Uchida T. 1932. Beiträge zur Kenntnis der japanischen Ichneumoniden. Insecta Matsumurana, 6, 145-168.

137. Uchida T. 1941. Eine neue Schmarotzerwespe von Spinnen. Insecta Matsumurana, 15(4), 161-162.

138. Uchida T, Momoi S. 1958. On the species of Polysphincta Gravenhorst and Zatypota Förster from Japan (Hymenoptera, Ichneumonidae). Insecta Matsumurana, 22(1-2), $22-30$.

139. Uchida T, Momoi S. 1959. On the species of the genera Laufeia and Lycorina occurring in Japan (Hymenoptera, Ichneumonidae). Insecta Matsumurana, 22(3-4), 82-87.

140. Vincent LS. 1979. A new record for Sinarachna anomala (Hymenoptera: Ichneumonidae), an external parasitoid of Mallos pallidus (Araneae: Dictynidae). Pan-Pacific Entomologist, 55(3), 192-194.

141. Walker F. 1874. Descriptions of some Japanese Hymenoptera. Cistula Entomologica, 1, 301-310.

142. Weng JL, Barrantes G. 2007. Natural history and larval behavior of the parasitoid Zatypota petronae (Hymenoptera : Ichneumonidae). Journal of Hymenoptera Research, 16(2), 326-335.

143. Wheeler WC, Coddington JA, Crowley LM, Dimitrov D, Goloboff PA, Griswold CE, Hormiga G, Prendini L, Ramírez MJ, Sierwald P, Almeida-Silva L, AlvarezPadilla F, Arnedo MA, Benavides Silva LR, Benjamin SP, Bond JE, Grismado CJ, Hasan E, Hedin M, Izquierdo MA, Labarque FM, Ledford J, Lopardo L, Maddison WP, Miller JA, Piacentini LN, Platnick NI, Polotow D, SilvaDávila D, Scharff N, Szúts T, Ubick D, Vink CJ, Wood HM, Zhang J. 2017. The spider tree of life: phylogeny of Araneae based on target-gene analyses from an extensive taxon sampling. Cladistics, 33(6), 574-616.

144. World Spider Catalog. 2017. World Spider Catalog, Version 18.5. Natural History Museum Bern. [Accessed on 21 Sep 2017].

Cite this article as: Takasuka K, Fritzén NR, Tanaka Y, Matsumoto R, Maeto K, Shaw MR. 2018. The changing use of the ovipositor in host shifts by ichneumonid ectoparasitoids of spiders (Hymenoptera, Ichneumonidae, Pimplinae). Parasite 25, 17 
O PARASTE

An international open-access, peer-reviewed, online journal publishing high quality papers on all aspects of human and animal parasitology

Reviews, articles and short notes may be submitted. Fields include, but are not limited to: general, medical and veterinary parasitology; morphology, including ultrastructure; parasite systematics, including entomology, acarology, helminthology and protistology, and molecular analyses; molecular biology and biochemistry; immunology of parasitic diseases; host-parasite relationships; ecology and life history of parasites; epidemiology; therapeutics; new diagnostic tools.

All papers in Parasite are published in English. Manuscripts should have a broad interest and must not have been published or submitted elsewhere. No limit is imposed on the length of manuscripts.

Parasite (open-access) continues Parasite (print and online editions, 1994-2012) and Annales de Parasitologie Humaine et Comparée (1923-1993) and is the official journal of the Société Française de Parasitologie. 